\title{
Serum Amino Acid Levels and Mortality in Patients Undergoing Percutaneous Endoscopic Gastrostomy
}

\author{
Ridvan Sivritepe ${ }^{1}$, Sema Ucak Basat ${ }^{2}$ and Neslihan Gokmen ${ }^{3}$ \\ ${ }^{1}$ Department of Internal Medicine, Faculty of Medicine, Istanbul Medipol University Pendik Hospital, Istanbul, Turkey \\ ${ }^{2}$ Department of Internal Medicine, University of Health Sciences Umraniye Training and Research Hospital, Istanbul, Turkey \\ ${ }^{3}$ Department of Basic Sciences, Istanbul Technical University, Istanbul, Turkey
}

\begin{abstract}
Objective: To evaluate the effect of feeding via percutaneous endoscopic gastrostomy tube (PEG) on serum amino acid levels and mortality.

Study Design: Descriptive study.

Place and Duration of Study: University of Health Sciences, Umraniye Training and Research Hospital, Istanbul, Turkey, from January 2016 to February 2019.

Methodology: Patients over 18 years of age, who were indicated for PEG due to loss of swallowing reflex, were included in the study. The follow-up period of the study was one year. The patients were reevaluated on the $3^{\text {td }}, 6^{\text {th }}$, and $12^{\text {th }}$ months after inclusion. Anthropometric measurements, and nutritional status were evaluated at each visit, and quantitative amino acid levels were analysed. Statistical significance was accepted as $p<0.05$.

Results: The study was carried out with a total of 53 cases (23 men and 30 women) ranging in the age from 18 to 91 years. While 13 patients were still alive, 40 patients died before completing one year. The levels of glutamine, leucine, taurine, and threonine were significantly different between surviving patients and dead. A statistically significant difference was found between the levels of citrulline $(p<0.001)$, ornithine $(p=0.036)$ and tyrosine $(p=0.011)$ during the four different visits of patients who survived. In patients who died, a significant difference was found between the levels of threonine, ornithine, and aspartic acid ( $p<0.043$ for all) between visits. Citrulline and tyrosine levels were found to be significantly increased in surviving patients.
\end{abstract}

Conclusion: The amino acid profiles of malnourished patients vary considerably. Increase in citrulline, ornithine and tyrosine levels are noted in surviving patients.

Key Words: Amino acid, Percutaneous endoscopic gastrostomy, Malnutrition, Mortality.

How to cite this article: Sivritepe R, Basat SU, Gokmen N. Serum Amino Acid Levels and Mortality in Patients Undergoing Percutaneous Endoscopic Gastrostomy. J Coll Physicians Surg Pak 2021; 31(11):1278-1284.

\section{INTRODUCTION}

Malnutrition is a syndrome that can lead to negative consequences such as progressive and widespread loss of muscle mass and strength, physical dependence, falls, low quality of life, and death; and can be seen in children and the elderly. ${ }^{1}$ Metabolic disorders of patients with malnutrition are quite complex. ${ }^{2}$ Malnutrition is an important catabolic process leading to a peripheral energy deficit caused by fragmentation of muscle proteins and increased oxidation of branched chain amino acids. ${ }^{3}$ Studies have shown correlations between the clinical status and specific laboratory values of malnourished patients. ${ }^{4}$

Correspondence to: Dr. Rıdvan Sivritepe, Department of Internal Medicine, Faculty of Medicine, Istanbul Medipol University Pendik Hospital, Istanbul, Turkey

E-mail: dr.ridvansivritepe@gmail.com

Received: April 15, 2021; Revised: October 11, 2021;

Accepted: October 15, 2021

DOI: https://doi.org/10.29271/jcpsp.2021.11.1278
However, there is no study showing the relationship between amino acid values and mortality rate in patients who were feeding with percutaneous endoscopic gastrostomy (PEG). The prognosis in any case of malnutrition is difficult to predict, but theoretically should be related to the degree of disruption in peripheral energy deficit. PEG is an indicated method for patients with normal gastrointestinal function, who require long-term enteral feeding. ${ }^{5}$ PEG is a palliative option for the prevention of malnutrition in cases with decreased / loss of swallowing reflex, except forterminal stage patients whose life span is less than 1-2 months. ${ }^{6}$ This study was conducted to evaluate the effect of feeding with PEG tube on mortality and quantitative serum amino acid levels.

\section{METHODOLOGY}

This study was designed as a prospective and self-controlled study. Ethics committee approval was obtained. All procedures performed in studies involving human participants were in accordance with the ethical standards of the institutional and 
national research committee and with the 1964 Helsinki Declaration, and its later amendments or comparable ethical standards. For the power analysis, the study by Su et al. was used as reference. ${ }^{7}$ Considering the correlation coefficient between sequential organ failure assessment score and taurine ( $r=-0.319$ ), the sample size was calculated as minimum 55 , with a type 1 error of 0.05 , and the strength of the study being $80 \%$. With a $20 \%$ loss, a total of 53 patients were incorporated in the study. Fifty-three patients over the age of 18 with PEG indication, who were hospitalised following the loss of swallowing reflex due to aging (age-related decrease in swallowing reflex) or neurological disease (chronic cerebrovascular disease, dementia, alzheimer's disease), were included in the study. Patients were included in the study in order of hospitalisation. Patients under the age of 18, who were feeding parenterally in the first 48 hours of hospitalisation, and with a history of major surgery, were not included. A detailed history was taken, and physical examinations were performed. The patients were reevaluated on the $3^{\text {rd }}, 6^{\text {th }}$, and $12^{\text {th }}$ months after first assessment.

The heights of the patients were measured with a height meter. Since most of the patients were bed-ridden, the last known weight of the patient was the current weight of the patients since the beds in the hospital do not have weight measurement features. Body mass index (BMl; $\mathrm{Kg} / \mathrm{m}^{2}$ ) was calculated using these measurements. Upper arm and calf circumference measurementswere performed using a tape measure. Measurements of arm circumference below $22 \mathrm{~cm}$ as low, and $22 \mathrm{~cm}$ and above as normal for men and below $20 \mathrm{~cm}$ as low, $20 \mathrm{~cm}$ and above as normal for women. Calf circumference below $31 \mathrm{~cm}$ : low, $31 \mathrm{~cm}$ and above: normal for men; and below $28 \mathrm{~cm}$ : low, 28 cmandabove: normalfor women. ${ }^{8}$

The mini nutritional assessment (MNA) questionnaire was used to evaluate the nutritional status of the patients. Assessment was as follows: under 17 points: malnutrition, between 17 and 23.5 points: under the risk of malnutrition, between 24 and 30 points: normal nutritional. ${ }^{9}$

Blood samples were taken from 8:00 am to 10:00 and analysed simultaneously. Blood glucose levels were analysed in whole blood by the enzymatic calorimetric methods, using commercialdevices. Calcium, phosphorus, alaninetransaminase, aspartate transaminase and albumin levels were measured using the enzymatic colorimetric test with a Hitachi 747 auto analyser (Mito, Ibaragi, Japan). Creatinine level with Jaffe', C-reactive protein with immunoassay, blood urea nitrogen level with spectrophotometer, potassium, and sodium with ion selective electrode were measured (Architect plus device, Abbot Diagnostics, Abbot Park, IL). Quantitative amino acid levels were measured using the tandem mass spectrometry technique, while GCmass spectrometry was measured using the HPLC method (ARCHITECT i2000SR immunoassay analyser, Abbot Diagnostics, Abbot Park, IL).

Patients included in the study were divided into four groups as $0^{\text {th }}$ month, $3^{\text {rd }}$ month, $6^{\text {th }}$ month, and $12^{\text {th }}$ month.
Power analysis was performed for sample size. The Statistical Package for the Social Sciences (SPSS) software programme, version 22.0 (IBM) was used. Descriptive statistical methods [mean \pm standard deviation, median (IQR: 25th percentile-75th percentile), frequency and percentage] were used to evaluate the study data. The paired sample t test was used for intragroup comparisons of quantitative data showing normal distribution, while the Wilcoxon signed ranks test was used for intragroup comparisons of parameters with abnormal distribution. The Friedman test was used to test whether the mean rank differed significantly from each other in the related measurements. ROC analysis was used to evaluate the relationship between survival times. The Cox regression (or proportional hazards regression) is a method for investigating the effect of several variables on the time a specified event (mortality) takes to happen. In the context of an outcome such as death, this is known as Cox regression for survival analysis. Significance was accepted as $p<0.05$.

\section{RESULTS}

The study had a total of 53 cases, 23 of whom were men $(43.4 \%)$ and 30 women (56.6\%), ranging in age from 18 to 91 years. The mean age was $78.53 \pm 13.39$ years. In survival analysis, 40 of 53 patients included in the study died. The last death was seen on the $318^{\text {th }}$ day, and the cumulative survival rate on this date was $25 \%$.

At the end of the present study, 40 (75.5\%) patients died while $13(24.5 \%)$ patients were alive. In the ROC analysis made by dividing the patients into two groups as patients who survived and patients who died, the cut-off values and the values under the curve of amino acids such as $3^{\text {rd }}$ month glutamine (AUC $=0.762,95 \%$ C.I: $0.565-0.958), \quad 3^{\text {rd }}$ month leucine $(A \cup C=0.715,95 \%$ C.I: $0.501-0.930), 6^{\text {th }}$ month leucine (AUC $=0,762,95 \%$ C.I: $0.541-0.982), 6^{\text {th }}$ month taurine (AUC $=0,723,95 \%$ C.I: $0.502-0.944)$, and $6^{\text {th }}$ month threonine ( $A U C=0,754,95 \%$ C.I: $0.528-0.980$ ) were found to be statistically significant ( $p<0.05$; for all, Figure 1).

A statistically significant difference was found between the measurements of citrulline, ornithine, tyrosine at $0,3,6$, and 12 months in during four visits of 13 patients who survived ( $p$ $<0.001$; p: 0.036; and p: 0.011, respectively, Tablel). There was no difference in other amino acid levels between visits.

In the analysis of patients who died, the $6^{\text {th }}$ month threonine values increased significantly compared to the baseline threonine values. Aspartic acid values increased at the $6^{\text {th }}$ month compared to the $3^{\text {rd }}$ month. There was also a significant increase in the $6^{\text {th }}$ month ornithine values compared to the baseline ornithine values (Table I). Parameters found to be significant, which are $\mathrm{MNA} 0^{\text {th }}$ month, bed sores $6^{\text {th }}$ month, upperarm circumference $(\mathrm{cm}) 0^{\text {th }}$ month and transferrin $0^{\text {th }}$ month in the comparisons made according to survival, were included in the multivariate Cox regression analysis. The Cox regression model was found as significant, and could be interpreted ( $p=0.013)$. The $6^{\text {th }}$ month bed sore was found to be significant $(p=0.046)$. A one unit change in $6^{\text {th }}$ month bed sore increases the death status by 4.512 (95\% CI for HR: 1.026-19.835). 
Table I: Comparison of amino acids with significant changes between visits.

\begin{tabular}{|c|c|c|c|c|c|}
\hline & Patients who survived $(n=13)$ & \multirow[b]{2}{*}{$\mathbf{p}^{*}$} & & \multirow{2}{*}{$\begin{array}{c}\text { Patients who died ( } \mathrm{n}: 40) \\
\begin{array}{c}\text { Median (IQR: 25th percentile-75th } \\
\text { percentile) }\end{array}\end{array}$} & \multirow[b]{2}{*}{$\mathbf{p}^{* *}$} \\
\hline & Median (IQR: 25th percentile-75th percentile) & & & & \\
\hline Citrulline $0^{\text {th }}$ Month & $17.8(11.8-21.0) \mu \mathrm{mol} / \mathrm{L}$ & \multirow{3}{*}{$<0.001$} & Threonine $0^{\text {th }}$ month & $98.1(80.4-129.4)(\mu \mathrm{mol} / \mathrm{L})$ & \multirow{3}{*}{0.043} \\
\hline Citrulline $3^{\text {rd }}$ Months & $26.4(20.8-45.1) \mu \mathrm{mol} / \mathrm{L}$ & & Threonine $3^{\text {rd }}$ month & $123.75(98.0-144.5)(\mu \mathrm{mol} / \mathrm{L})$ & \\
\hline Citrulline $6^{\text {th }}$ Months & $31.9(29.5-46.8) \mu \mathrm{mol} / \mathrm{L}$ & & Threonine $6^{\text {th }}$ month & $126.0(124.0-144.0)(\mu \mathrm{mol} / \mathrm{L})$ & \\
\hline Citrulline $12^{\text {th }}$ Months & $43.21(32.2-58.4) \mu \mathrm{mol} / \mathrm{L}$ & - & Threonine $12^{\text {th }}$ month & - & - \\
\hline Tyrosine $0^{\text {th }}$ Month & $37.8(35.5-46.1) \mu \mathrm{mol} / \mathrm{L}$ & \multirow{3}{*}{0.036} & Ornithine $0^{\text {th }}$ month & $81.9(58.1-98.3)(\mu \mathrm{mol} / \mathrm{L})$ & \multirow{3}{*}{0.043} \\
\hline Tyrosine $3^{\text {rd }}$ Months & $45.8(42.1-64.8) \mu \mathrm{mol} / \mathrm{L}$ & & Ornithine $3^{\text {rd }}$ month & $94.65(57.7-96.5)(\mu \mathrm{mol} / \mathrm{L})$ & \\
\hline Tyrosine $6^{\text {th }}$ Months & $50.2(49.0-59.1) \mu \mathrm{mol} / \mathrm{L}$ & & Ornithine $6^{\text {th }}$ month & $104.0(92.4-106.0)(\mu \mathrm{mol} / \mathrm{L})$ & \\
\hline Tyrosine $12^{\text {th }}$ Months & $52.4(48.0-57.0) \mu \mathrm{mol} / \mathrm{L}$ & - & Ornithine $12^{\text {th }}$ month & - & - \\
\hline Ornithine $0^{\text {th }}$ Month & $77.5(55.4-97.7) \mu \mathrm{mol} / \mathrm{L}$ & \multirow{3}{*}{0.011} & Aspartic acid $0^{\text {th }}$ month & $4.3(3.0-6.4)(\mu \mathrm{mol} / \mathrm{L})$ & \multirow{3}{*}{0.043} \\
\hline Ornithine $3^{\text {rd }}$ Months & $62.0(51.0-103.3) \mu \mathrm{mol} / \mathrm{L}$ & & Aspartic acid $3^{\text {rd }}$ month & $6.0(5.0-7.9)(\mu \mathrm{mol} / \mathrm{L})$ & \\
\hline Ornithine $6^{\text {th }}$ Months & $104.7(84.5-155.0) \mu \mathrm{mol} / \mathrm{L}$ & & Aspartic acid $6^{\text {th }}$ month & $7.0(6.2-9.2)(\mu \mathrm{mol} / \mathrm{L})$ & \\
\hline Ornithine $12^{\text {th }}$ Months & $117.9(95.8-156.4) \mu \mathrm{mol} / \mathrm{L}$ & - & Aspartic acid $12^{\text {th }}$ month & - & - \\
\hline
\end{tabular}

Table II: Comparison of all amino acids in all patients according to baseline levels.

\begin{tabular}{|c|c|c|c|c|c|c|c|}
\hline & $0^{\text {th }}$ month & $3^{\text {rd }}$ months & $6^{\text {th }}$ months & $12^{\text {th }}$ months & \multirow{2}{*}{$\mathbf{p}^{1}$} & \multirow{2}{*}{$\mathbf{p}^{2}$} & \multirow{2}{*}{$\mathbf{p}^{3}$} \\
\hline & Avg \pm S.D/ Median (IQR) & Avg \pm S.D / Median (IQR) & Avg \pm S.D / Median (IQR) & Avg \pm S.D / Median (IQR) & & & \\
\hline Glycine $(\mu \mathrm{mol} / \mathrm{L})$ & $109.7 \pm 127.9 / 83(63.4-100.8)$ & $91.3 \pm 50.2 / 71.5(67.4-94.8)$ & $103.59 \pm 55.18 / 86.2(70.4-109)$ & $87.13 \pm 55.54 / 78.6(53.8-88)$ & 0.533 & 0.983 & 0.807 \\
\hline Alanine $(\mu \mathrm{mol} / \mathrm{L})^{*}$ & $189.7 \pm 182.2 / 134.2(109.1-214)$ & $202.13 \pm 140.65 / 146.5(113.3-242.6)$ & $233.83 \pm 166.6 / 168(136.4-266.57)$ & $225.53 \pm 98.56 / 219.8(140.2-275)$ & 0.838 & 0.086 & 0.158 \\
\hline Alpha amino butyridine $(\mu \mathrm{mol} / \mathrm{L})$ & $189 \pm 128.8 / 171.7$ (137.4-222.6) & $198.56 \pm 63.46 / 204.8(153.6-244.1)$ & $244.76 \pm 103.63 / 222.55(192.7-241)$ & $226.12 \pm 70.49 / 238(191.1-255)$ & 0.378 & 0.776 & 0.084 \\
\hline Serine $(\mu \mathrm{mol} / \mathrm{L})$ & $120.9 \pm 98.7 / 99(79.3-129.9)$ & $118.49 \pm 60.95 / 104.2(66.9-144.5)$ & $123.4 \pm 67.48 / 105.7$ (74.5-144) & $96.79 \pm 29.38 / 102.4(81.4-116)$ & 0.465 & 0.5 & 0.064 \\
\hline Proline $(\mu \mathrm{mol} / \mathrm{L})$ & $55.8 \pm 40.3 / 46.7(29.7-63.4)$ & $59.66 \pm 51.47 / 44.8(28.9-74.5)$ & $73.13 \pm 63.4 / 48.85$ (36.7-98.9) & $79.36 \pm 77.55 / 48.7(29-68.9)$ & 0.584 & 0.248 & 0.101 \\
\hline Valine $(\mu \mathrm{mol} / \mathrm{L})$ & $70.2 \pm 97.2 / 51.8(40.9-74)$ & $65.05 \pm 28.79 / 59(46.84-74.8)$ & $69.85 \pm 34.6 / 60.95(47-71.2)$ & $70.5 \pm 35.2 / 62(52.5-82.4)$ & 0.627 & 0.157 & 0.059 \\
\hline Threonine $(\mu \mathrm{mol} / \mathrm{L})$ & $106.75 \pm 120.79 / 91.1(70.1-113)$ & $105.21 \pm 30.78 / 103.2(91.3-123.4)$ & $117.3 \pm 37.05 / 111.75(102-129.4)$ & $101.9 \pm 32.3 / 108(100-112)$ & 0.808 & 0.42 & 0.279 \\
\hline Taurine $(\mu \mathrm{mol} / \mathrm{L})$ & $41.6 \pm 23.1 / 35(26.8-50)$ & $48.29 \pm 23.48 / 44$ (31.1-72.1) & $47.73 \pm 19.07 / 42.25(38-64)$ & $50.39 \pm 24.6 / 48(37.57-60)$ & 0.808 & 0.248 & 0.422 \\
\hline Isoleucine $(\mu \mathrm{mol} / \mathrm{L})$ & $9.5 \pm 17.3 / 4.5(2.9-6.2)$ & $6.23 \pm 2.6 / 5.6(4.1-7.9)$ & $6.69 \pm 2.33 / 6.89(5-8.4)$ & $5.95 \pm 3.03 / 4.8(4.6-6.9)$ & 0.301 & 0.327 & 0.311 \\
\hline Leucine $(\mu \mathrm{mol} / \mathrm{L})^{*}$ & $376.3 \pm 160.2 / 375(280.8-467)$ & $441.34 \pm 187.18 / 448.7(289.2-550.8)$ & $524.3 \pm 214.5 / 536(445-624.8)$ & $482.84 \pm 194.79 / 481(423.1-654)$ & 0.479 & 0.188 & 0.898 \\
\hline Asparagine $(\mu \mathrm{mol} / \mathrm{L})^{*}$ & $80.1 \pm 131.1 / 58.9(38-84.1)$ & $68.19 \pm 21.79 / 76.1(46.4-87.3)$ & $77.87 \pm 37.06 / 70.7$ (53.1-91.4) & $72.2 \pm 33.1 / 71.8(49-93)$ & 0.364 & 0.654 & 0.295 \\
\hline Aspartic Acid $(\mu \mathrm{mol} / \mathrm{L})$ & $30.9 \pm 66.7 / 19.2(11.9-27.6)$ & $22.88 \pm 14.71 / 19.1(14.9-27.2)$ & $24.37 \pm 16.71 / 18.45(16.4-25.4)$ & $21.34 \pm 14.05 / 19.5(14.5-23.6)$ & 0.235 & 0.133 & 0.6 \\
\hline Glutamine $(\mu \mathrm{mol} / \mathrm{L})$ & $62.9 \pm 76.5 / 51.4(41.1-65.4)$ & $63.03 \pm 23.57 / 60.4(45.7-73.6)$ & $74.27 \pm 25.29 / 69.2(60.35-91.6)$ & $69.46 \pm 23.84 / 73(52.6-82.5)$ & 0.171 & 0.012 & 0.116 \\
\hline Glutamic acid ( $\mu \mathrm{mol} / \mathrm{L})$ & $87.8 \pm 96.4 / 67.8$ (54.3-89) & $76.83 \pm 26.8 / 74.9(61.5-94.6)$ & $75.65 \pm 32.04 / 66.3(57.8-95.4)$ & $76.58 \pm 39.17 / 66(57.28-92)$ & 0.574 & 0.647 & 0.221 \\
\hline Methionine $(\mu \mathrm{mol} / \mathrm{L})$ & $75.1 \pm 146.9 / 47.2(25.2-67.9)$ & $72.24 \pm 54.88 / 54.4(25-106.5)$ & $77.05 \pm 35.25 / 65.7(58.7-79.6)$ & $86.26 \pm 42.72 / 80(66.4-84.5)$ & 0.749 & 0.913 & 0.075 \\
\hline Histidine $(\mu \mathrm{mol} / \mathrm{L})$ & $21.79 \pm 16.63 / 17.8(12.4-24.8)$ & $36.76 \pm 23.27 / 33.8(19-50.1)$ & $44.43 \pm 21.37 / 38.75(30.5-49.8)$ & $47.41 \pm 19.74 / 43.21(32.2-58.4)$ & 0.024 & 0.018 & 0.087 \\
\hline Phenylalanine $(\mu \mathrm{mol} / \mathrm{L})$ & $45.5 \pm 13.4 / 44.7(36.5-56.1)$ & $58.42 \pm 21.42 / 52.2(44-68.4)$ & $63.76 \pm 36.43 / 53(49-59.1)$ & $56.07 \pm 24.2 / 52.4(48-57)$ & 0.988 & 0.811 & 0.917 \\
\hline Arginine $(\mu \mathrm{mol} / \mathrm{L})$ & $33.6 \pm 25.1 / 30.5(20.4-38.9)$ & $33.97 \pm 10.15 / 36.9(23.6-42.3)$ & $39.59 \pm 11.57 / 39.6$ (38-49.23) & $38.7 \pm 9.9 / 42.1(37.6-42.5)$ & 0.761 & 0.145 & 0.196 \\
\hline Citrulline $(\mu \mathrm{mol} / \mathrm{L})$ & $82.3 \pm 36.3 / 81.4$ (56.4-98.3) & $93.68 \pm 63.45 / 90.1(53.99-103.3)$ & $108.8 \pm 43.07 / 104.35(84.5-138.2)$ & $127.07 \pm 49.26 / 117.9(95.83-156.4)$ & 0.003 & $<0.001$ & 0.002 \\
\hline Tyrosine $(\mu \mathrm{mol} / \mathrm{L})$ & $165.4 \pm 132.3 / 132.4$ (105.4-158) & $175.36 \pm 87.14 / 149.8(107.7-231.2)$ & $172.85 \pm 55.65 / 148.8(137.8-194.5)$ & $162.27 \pm 34.95 / 162.4(139.81-188)$ & 0.026 & 0.02 & 0.064 \\
\hline Tryptophan $(\mu \mathrm{mol} / \mathrm{L})$ & $0.2 \pm 0.2 / 0.1(0.1-0.1)$ & $0.2 \pm 0.3 / 0.1(0.1-0.1)$ & $0.1 \pm 0.1 / 0.1(0.1-0.1)$ & $0.1 \pm 0.1 / 0.1(0.1-0.1)$ & 0.976 & 0.327 & 0.152 \\
\hline Ornithine $(\mu \mathrm{mol} / \mathrm{L})$ & $12.2 \pm 5.5 / 0(0-5)$ & $15.7 \pm 3.9 / 8(0-12)$ & $18.1 \pm 3.5 / 8(5-10)$ & $20.3 \pm 3.6 / 10(8-14)$ & 0.326 & 0.010 & 0.011 \\
\hline Lysine $(\mu \mathrm{mol} / \mathrm{L})$ & $2 \pm 1 / 3(2-3)$ & $1 \pm 1 / 1(0-2)$ & $0 \pm 1 / 0(0-0)$ & $0 \pm 0 / 0(0-0)$ & 0.429 & 0.112 & 0.173 \\
\hline Arginineo succinic Acid ( $\mu \mathrm{mol} / \mathrm{L})$ & $22.4 \pm 3.4 / 20(18-23)$ & $22.1 \pm 3.3 / 22(20-24)$ & $23.2 \pm 3.5 / 23(21-25)$ & $24.3 \pm 3.4 / 25(22-25)$ & 0.44 & 0.128 & 0.144 \\
\hline
\end{tabular}

Changes in the amino acids of all patients are summarised in Table II. The MNA scores, hand dynamometers, bed sores, albumin, C-reactive protein, iron binding capacity, ferritin, phosphorus, calcium, hemoglobin levels of the patients, who were to be fed via PEG, began to improve significantly in the 3rd month; and this positive state continued in the 6th and 12th months. Parameters such as upper arm circumference, calf circumference, weight, BMI, get up and go test and iron began to increase on the 6th month.

The histidine and tyrosine levels of the patients increased in the 3rd and 6th months compared to the baseline levels. Citrulline levels tended to increase compared to baseline levels at all three visits. Ornithine levels tended to increase in the 6th and 12th months compared to the baseline levels.

\section{DISCUSSION}

In the present study, the effect of PEG on serum amino acid levels in malnourished patients was investigated. This study is valuable because it is the first study to investigate the effect of feeding with PEG on survival and serum quantitative amino acid levels.

There was a significant difference in citrulline, ornithine and tyrosine levels between visits of 13 patients who survived. In patients who died, threonine, aspartic acid and ornithine levels were also found to be significantly increased. Muscle tissue is an important organ that performs protein storage, glucose regulation, hormone production and other cellular mechanisms. ${ }^{10}$ Malnutrition is defined as a syndrome characterised by generalised and progressive loss of muscle mass and strength, which can lead to poor outcomes such as physical disability, poor quality of life and death. ${ }^{11}$ 


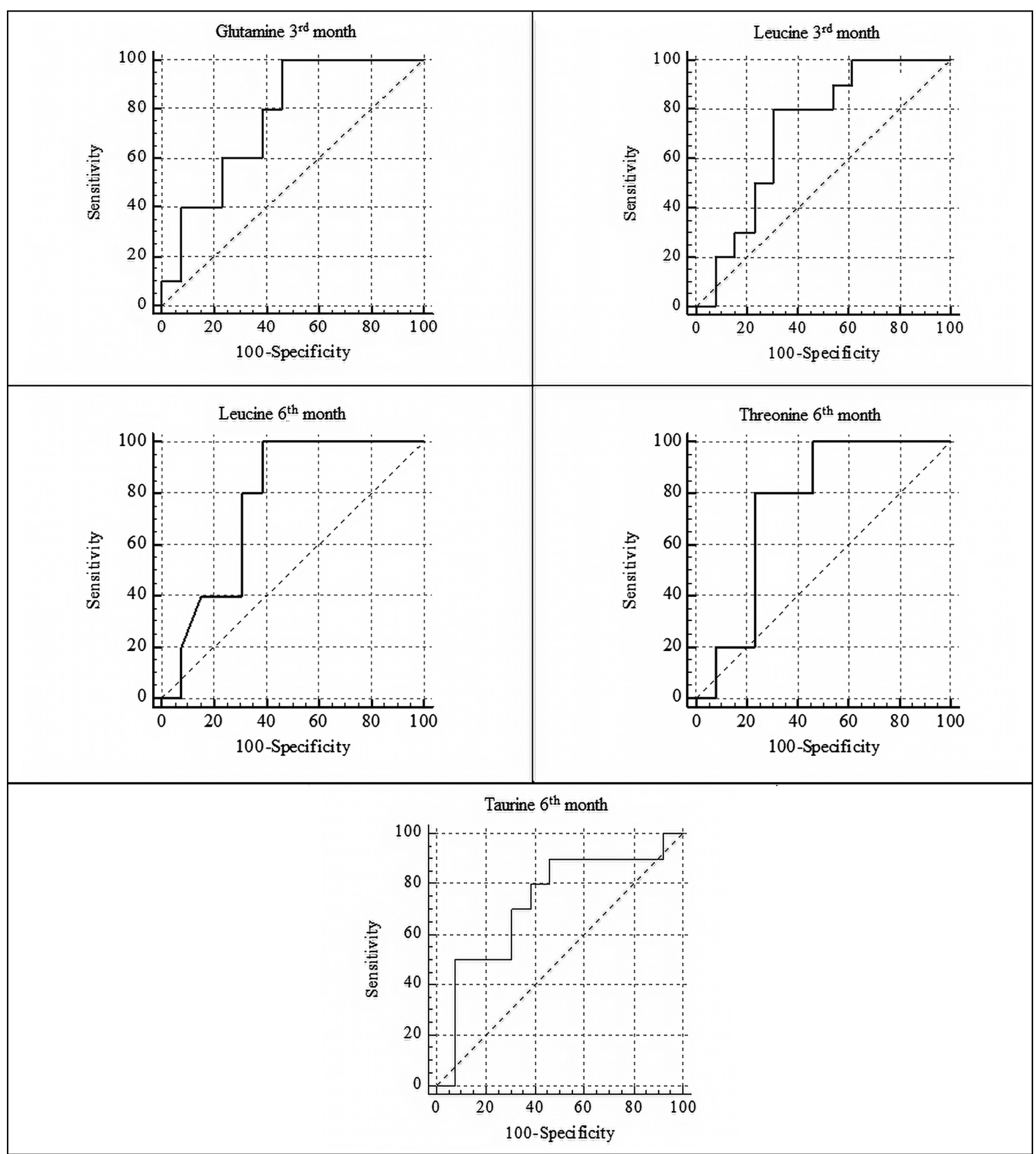

Figure 1: Significant amino acids in ROC analysis.

The pathophysiology of malnutrition is complicated in the elderly. ${ }^{12}$ If this pathological process involving many mechanisms is not treated immediately, muscle degeneration and impaired immune response may delay healing and increase mortality. Therefore, detection of these metabolic disorders is important for clinical management in these patients.
There are variable data in the literature about the life expectancy of patients fed with PEG. The first death occurred on day 2 and the last death occurred on day 318 during the present study period. The survival time of the 13 patients was also more than 365 days. The lack of any study on the effect of quantitative amino acid levels on life 
expectancy, malnutrition, physical performance, and muscle strength in these patients makes this study very important.

Feeding with PEG is the most effective and safest option to feed patients with a normal digestive system, but with reduced swallowing reflex. ${ }^{13}$ In this study, as in the study by Erdil et al., nutritional parameters rapidly improve in patients fed by PEG. ${ }^{14}$

In the present study, concentration of some amino acids was found to be increased, some fluctuated, and most of them did not change. In a study conducted in critically ill patients in the intensive care unit, sulfur-containing amino acids, especially taurine, were found to be lower in patients with severe sepsis. ${ }^{7}$ However, in the present study, there was no association between taurine levels with survival or mortality. In the same study, the concentrations of arginine, glutamine, phenylalanine, taurine, aspartic acid, ethanolamine, homocysteine, and glutamic acid were found to be significantly higher in sepsis patients. ${ }^{7}$ In the present study, a significant increase in threonine, aspartic acid and ornithine levels was found close to the time of death in patients who died. These results show that aspartic acid may be an indicator of mortality in patients with severe metabolic problems due to malnutrition. In another study, lower levels of leucine, isoleucine, and valine have been shown to promote protein catabolism and decrease muscle protein synthesis. ${ }^{15}$ However, in the present study, these amino acids were not associated with either survival or mortality.

The levels of citrulline, ornithine, and tyrosine increased gradually in 13 patients who survived in the present study. Supplementation of these amino acids in these patients may contribute positively to mortality. A study in critically ill patients showed that consumption of proline, histidine, and the ornithine increased, but levels of arginine, glutamine, and glutamic acid remained high. This balance plays an important role in the regulation of acid / base homeostasis, fibroblast, lymphocyte and enterocyte growth and the total amount of protein in the skeletal muscle. ${ }^{16}$ In the present study, ornithine level was increased gradually both in patients who survived and in patients who died. This study was in contradiction with the current data in the literature on this subject.

Citrulline is associated with gastrointestinal system disorders. ${ }^{17}$ In this study, the authors found that the citrulline levels of surviving patients gradually increased due to active use of the gastrointestinal tract after PEG. Citrulline has been shown to improve vascular function, reduce blood pressure and increase peripheral blood flow by increasing the synthesis of nitric oxide. This situation increases oxygenation of peripheral muscle tissue and causes an increase in muscle function and strength. ${ }^{18}$ In a study conducted in infantile rats, it was shown that citrulline supplementation increased the interleukin-10 level by increasing the production of interferon-gamma, which in turn affected functions of the Tregulator cell. ${ }^{19}$ Citrulline level also increased significantly in patients who survived in this study. This significant effect of the citrulline level on the survivors of the patients can be explained by the increase in peripheral oxygenation and regulation of the immune system.

Tyrosine is a semi-essential amino acid in humans. It is synthesised from phenylalanine by adding a hydroxyl group to the aromatic ring. ${ }^{20}$ In vivo, tyrosine plays an important role in the synthesis of catecholamine, thyroxine, dopamine, norepinephrine and epinephrine and melanin. Tyrosine is an essential amino acid that easily crosses the blood-brain barrier. Therefore, it is an important part of the body's sympathetic nervous system. ${ }^{21}$ People who are under stress need more tyrosine. Tyrosine supplementation in these individuals increases the resistance of the metabolism against stress by preventing depletion of norepinephrine. ${ }^{22}$ In this study, the tyrosine level increased significantly in patients who survived. In the present study, the positive effect of tyrosine amino acid on survival was shown. This effect is shown by increasing the endurance of the organism under stress by decreasing the consumption of epinephrine and norepinephrine in the catabolic process of our malnourished patients.

Threonine, an essential amino acid for the nervous system, also plays an important role in fat metabolism. ${ }^{23}$ It has important functions, especially in collagen tissue. ${ }^{23}$ In this study, threonine level increased significantly in patients who survived. This significant effect of the threonine level on both bed wounds and survivors can be explained by its regulatory role of collagen and adipose tissue.

Ornithine is known to increase liver function and help detoxification of harmful substances. ${ }^{24}$ It is claimed that ornithine positively affects wound healing, increases physical performance and the immune system. ${ }^{24}$ Catabolic states such as burns affect the ornithine level in tissues in the body. ${ }^{25}$ In the present study, it was found that the level of ornithine was increased in the follow-up of both the dead and surviving patients. The authors could not explain the relationship of ornithine level with both survival and mortality.

The present study had some limitations. Amino acid levels were evaluated at four different time points. It was not a cohort study so that the authors could not establish a causal relationship between quantitative amino acid and mortality and survival.

\section{CONCLUSION}

The amino acid profiles of patients with malnutrition clearly changed. The present study results suggest a close and significant relationship between impaired energy metabolism 
and muscle protein degradation in severely malnourished patients. There is a close and significant relationship between impaired energy metabolism and muscle protein destruction in patients with severe malnutrition. Increased citrulline, ornithine, and tyrosine levels are noteworthy in patients who survived. This study provides a theoretical basis for nutritional support in the treatment of patients with malnutrition and PEG implantation. Additional treatments containing citrulline and tyrosine may be beneficial for recovery, but clinical randomised controlled trials are needed to confirm these results.

\section{ETHICAL APPROVAL:}

The study was approved by the Institutional Ethics Committee of University of Health Sciences, Umraniye Training and Research Hospital. (Date: 19.11.2015; Number: B.10.1.TKH.4.34.H.GP.0.01/85).

\section{PATIENTS' CONSENT:}

Informed consents were obtained from all patients / relatives before the study began.

\section{CONFLICT OF INTEREST:}

The authors declared no conflict of interest.

\section{AUTHORS' CONTRIBUTION:}

RS, SUB, NG: Conception and design, data acquisition, data analysis and interpretation. Manuscript drafting and critical revision of the manuscript, statistical analysis, supervision.

\section{REFERENCES}

1. Sieber CC. Malnutrition and sarcopenia. Aging Clin Exp Res 2019; 31(6):793-8. doi: 10.1007/s40520-019-01170-1.

2. Zhang Z, Pereira SL, Luo M, Matheson EM. Evaluation of blood biomarkers associated with risk of malnutrition in older adults: A Systematic Review and Meta-Analysis. Nutrients 2017; 9(8):829. doi: 10.3390/nu9080829.

3. Gurina TS, Mohiuddin SS. Biochemistry, Protein Catabolism. In: StatPearls. Treasure Island (FL): StatPearls Publishing; 2021 Jan. Available from: http://www.ncbi.nlm.nih.gov/ books/NBK556047/.

4. Reber E, Gomes F, Vasiloglou MF, Schuetz P, Stanga Z. Nutritional Risk Screening and Assessment. J Clin Med 2019; 8(7):1065. doi: 10.3390/jcm8071065.

5. Petrovskiy AN, Popov AY, Baryshev AG. Chreskozhnaia éndoskopicheski-assistirovannaia gastrostomiia [Percutaneous endoscopic gastrostomy]. Khirurgiia 2019; 8:69-73. doi: 10.17116/hirurgia201908169.

6. Hoffman MR. Tracheostomies and PEGs: When are they really Indicated? Surg Clin North Am 2019; 99(5):955-65. doi: 10.1016/j.suc.2019.06.009.

7. Su L, Li H, Xie A, Liu D, Rao W, Lan L, et al. Dynamic changes in amino acid concentration profiles in patients with sepsis. PLoS One 2015; 10(4):e0121933. doi: 10.1371/ journal.pone.0121933.
8. Selvaraj K, Jayalakshmy R, Yousuf A, Singh AK, Ramaswamy $G$, Palanivel C. Can mid-upper arm circumference and calf circumference be the proxy measures to detect undernutrition among elderly? Findings of a communitybased survey in rural Puducherry, India. J Family Med Prim Care 2017; 6(2):356-9. doi: 10.4103/jfmpc.jfmpc_357_16.

9. Guigoz Y, Vellas B, Garry PJ. Assessing the nutritional status of the elderly: The mini nutritional assessment as part of the geriatric evaluation. Nutr Rev 1996; 54(1 Pt 2):S59-65. doi: 10.1111/j.1753-4887.1996.tb03793.x.

10. Giudice J, Taylor JM. Muscle as a paracrine and endocrine organ. Curr Opin Pharmacol 2017; 34:49-55. doi: 10.1016/j. coph.2017.05.005.

11. Corish CA, Bardon LA. Malnutrition in older adults: Screening and determinants. Proc Nutr Soc 2019; 78(3): 372-9. doi: 10.1017/S0029665118002628.

12. De Bandt JP. Comprendre la physiopathologie de la dénutrition pour mieux la traiter [Understanding the pathophysiology of malnutrition for better treatment]. Ann Pharm Fr 2015; 73:332-5. doi: 10.1016/j.pharma.2015. 03.002.

13. Dietrich CG, Schoppmeyer K. Percutaneous endoscopic gastrostomy - Too often? Too late? Who are the right patients for gastrostomy? World J Gastroenterol 2020; 26(20):2464-71. doi: 10.3748/wjg.v26.i20.2464.

14. Erdil A, Saka M, Ates Y, Tuzun A, Bagci S, Uygun A, et al. Enteral nutrition via percutaneous endoscopic gastrostomy and nutritional status of patients: Five-year prospective study. J Gastroenterol Hepatol 2005; 20(7):1002-7. doi: 10.1111/j.1440-1746.2005.03892.x.

15. De Bandt JP, Cynober L. Therapeutic use of branched-chain amino acids in burn, trauma, and sepsis. J Nutr 2006; 136(1 Suppl):308S-13S. doi: 10.1093/jn/136.1.308S.

16. Tapiero $H$, Mathé $G$, Couvreur $P$, Tew KD. II. Glutamine and glutamate. Biomed Pharmacother 2002; 56(9):446-57. doi: 10.1016/s0753-3322(02)00285-8.

17. Blaser A, Padar M, Tang J, Dutton J, Forbes A. Citrulline and intestinal fatty acid-binding protein as biomarkers for gastrointestinal dysfunction in the critically ill. Anaesthesiol Intensive Ther 2019; 51(3):230-239. doi: 10.5114/ait.2019. 86049.

18. Figueroa A, Wong A, Jaime SJ, Gonzales JU. Influence of Lcitrulline and watermelon supplementation on vascular function and exercise performance. Curr Opin Clin Nutr Metab Care 2017; 20(1):92-8. doi: 10.1097/MC0.00000000 00000340.

19. Lee YC, Su YT, Liu TY, Tsai CM, Chang CH, Yu HR. L-Arginine and L-Citrulline Supplementation Have Different Programming Effect on Regulatory T-Cells Function of Infantile Rats. Front Immunol 2018; 9:2911. doi: 10.3389/fimmu.2018. 02911.

20. Bartesaghi S, Radi R. Fundamentals on the biochemistry of peroxynitrite and protein tyrosine nitration. Redox Biol 2018; 14:618-25. doi: 10.1016/j.redox.2017.09.009.

21. Nisimura LM, Bousquet $P$, Muccillo F, Tibirica E, Garzoni LR. Tyrosine hydroxylase and $\beta 2$-adrenergic receptor expression in leukocytes of spontaneously hypertensive rats: Putative peripheral markers of central sympathetic activity. Braz J Med Biol Res 2020; 53(12):e9615. doi: 


\section{$10.1590 / 1414-431 \times 20209615$.}

22. Jongkees BJ, Hommel B, Kühn S, Colzato LS. Effect of tyrosine supplementation on clinical and healthy populations under stress or cognitive demands--A review. J Psychiatr Res 2015; 70:50-7. doi: 10.1016/j.jpsychires. 2015.08.014.

23. Malinovsky AV. Reason for Indispensability of threonine in humans and other mammals in comparative aspect. Biochemistry 2017; 82(9):1055-60. doi: 10.1134/S0006297 917090097.
24. de Oliveira LF, Navarro BV, Cerruti GV, Elbl P, Minocha R, Minocha SC, et al. Polyamine- and amino acid-related metabolism: The roles of arginine and ornithine are associated with the embryogenic potential. Plant Cell Physiol 2018; 59(5):1084-98. doi: 10.1093/pcp/pcy049.

25. Pan M, Lu C, Zheng M, Zhou W, Song F, Chen W, et al. Unnatural amino-acid-based star-shaped poly (I-Ornithine)s as emerging long-term and biofilm-disrupting antimicrobial peptides to treat pseudomonas aeruginosa-ınfected burn wounds. Adv Healthc Mater 2020; 9(19):e2000647. doi: 10.1002/adhm.202000647. 